\title{
Carbon Dioxide Emissions in Agricultural Systems in the Brazilian Savanna
}

\author{
Jéssica Pereira de Souza ${ }^{1}$, Elisandra Solange Oliveira Bortolon ${ }^{2}$, Leandro Bortolon ${ }^{2}$, \\ Francelino Peteno de Camargo ${ }^{2}$, Willian Sousa Silva Conceição ${ }^{3}$, Alan de Ornelas Lima ${ }^{3}$ \\ $\&$ Fabiane Machado Vezzani ${ }^{4}$ \\ ${ }^{1}$ Universidade Federal do Rio Grande do Sul, Porto Alegre, Brazil \\ ${ }^{2}$ Embrapa Pesca e Aquicultura, Palmas, Brazil \\ ${ }^{3}$ Faculdade Católica do Tocantins, Palmas, Brazil \\ ${ }^{4}$ Universidade Federal do Paraná, Curitiba, Brazil \\ Correspondence: Leandro Bortolon, Embrapa Pesca e Aquicultura, Prolongamento da Avenida NS 10, \\ cruzamento com a Avenida LO 18, sentido Norte, s/n, Loteamento Água Fria, Palmas, TO, 77008-900, Brazil. \\ Tel: 55-63-3229-7825. E-mail: leandro.bortolon@embrapa.br
}

Received: July 11, 2019

doi:10.5539/jas.v11n17p242
Accepted: August 20, $2019 \quad$ Online Published: October 15, 2019

URL: https://doi.org/10.5539/jas.v11n17p242

The research is financed by Embrapa, CNPq and Fundação Agrisus.

\begin{abstract}
The objectives of this work were to evaluate the $\mathrm{CO}_{2}$ emission potential of an Oxisol under integrated crop-livestock and no-tillage systems in the Brasilian Savanna; and to analyze the impact of soil temperature and soil moisture as factors that regulate the seasonality and the emission of $\mathrm{C}_{-} \mathrm{CO}_{2}$ in these systems. Field-scale study was carried out at Fazenda Brejinho, in Pedro Afonso-TO, under Oxisol. The production systems studied were integrated crop-livestock and no-tillage under cropped with soybean and corn. The amount of carbon (C) released from the soil in the form of $\mathrm{CO}_{2}\left(\mathrm{C}-\mathrm{CO}_{2}\right)$ was evaluated using cylindrical chambers installed in the field with a vial containing sodium hydroxide to collect $\mathrm{CO}_{2}$ released from the soil (soil emission) in an interval of 15 hours. Five evaluations were conducted over crops growing season, started in 01/26 through 06/16/2015. Data were tested to analysis of variance and the means were compared with Duncan test at $5 \%$. The emission of $\mathrm{C}-\mathrm{CO}_{2}$ differed between treatments in all evaluation periods. On average, the temperature ranged from 26.5 to $27.7^{\circ} \mathrm{C}$, the soil moisture ranged from 12.2 to $15.7 \%$ and the $\mathrm{C}^{-\mathrm{CO}_{2}}$ emission ranged from 87.4 to $119.9 \mathrm{mg} \mathrm{m}^{-2}$ $\mathrm{h}^{-1}$. Temperature, soil moisture and the production systems contributed to the emission and seasonality of carbon dioxide emissions. The integrated crop-livestock cropped with soybean/corn rotation was the system that had the lowest carbon dioxide emission.
\end{abstract}

Keywords: integrated crop-livestock system, no-tillage, soil temperature, soil moisture

\section{Introduction}

The Tocantins state is part of the considered last Brazilian agricultural frontier for grain production (Horvat et al., 2015). This region belongs to the low altitude Savanna biome that is characterized by high temperatures (both during the day and the night), high rainfall within a period of five months followed by seven dry months (Bortolon et al., 2016). The soils of the Savanna contain low contents of organic material, are highly weathered, and are composed of phyllosilicates 1:1 and iron and aluminium oxides. They are considered fragile with a high probability of being found in a degraded state (Donagemma et al., 2016). The increase and maintenance of fertility of these soils is based on the increment of the content of soil organic material (SOM). This is because SOM is responsible to increase the cation exchange capacity, SOM is the source of the energy necessary to sustain biological processes and it is an agent in the formation and stabilization of soil aggregates (Tisdall \& Oades, 1982; Six et al., 2004). The combined action of these properties allows the soil system to perform essential functions within the ecosystem (Prado et al., 2001). Given that, sustainable crop production systems have to contribute to the increase in SOM. One of the key agricultural practices to achieve this goal is the no-tillage system (NTS) (Bayer et al., 2006, 2016; Carvalho et al., 2009) with the insertion of pasture (integrated 
crop-livestock system-ICLS) (Salton et al., 2014). The absence of ploughing allows the natural organization of the soil system and the deceleration in the process of SOM mineralization. Forages have fasciculated roots that improve soil structure and increase the capacity of the soil to stock organic carbon, which leads to the reduction in the carbon dioxide $\left(\mathrm{CO}_{2}\right)$ emission into the atmosphere (Tisdall \& Oades, 1982; Lal, 2004) contributing to the mitigation of greenhouse gases (GHGs).

The emission of $\mathrm{CO}_{2}$ from the soil is the result of edaphic microbial activity during the degradation of SOM and plant root respiration. The addition of crop residues to the soil that generate SOM occurs by root exudates and residues from the aboveground biomass and belowground biomass (roots) of the plants. SOM presents functional groups that under the $\mathrm{pH}$ conditions usually found in Savanna soils $(>5)$ are deprotonated generating a net negative charge. Thus, these groups can interact with the iron and aluminium oxides that normally present net positive charges under the same conditions and are generally found in abundance in Savanna soils. This chemical interaction protects SOM from the action of the enzymes produced by the edaphic microorganisms (Cotrufo et al., 2015). However, SOM that is not associated with minerals can be metabolized by the soil microbiota and have two pathways: (1), to be incorporated in to cellular components (anabolism) increasing the microbial biomass or; (2), broken down into $\mathrm{CO}_{2}$ and $\mathrm{NH}_{4}{ }^{+}$(Dippold \& Kuzyakov, 2013) and released into the atmosphere. The metabolic pathway followed depends on the concentration and composition of the plant residues added to the system and these will influence the functionality of the soil microbiota, mainly the carbon and nitrogen cycles (Blaud et al., 2012; Dippold \& Kuzyakov, 2013; Zhang et al., 2015).

Besides the molecular characteristics of the plants that compose the soil system, factors that alter microbial growth, such as soil temperature and soil moisture, can also modify the rate of $\mathrm{CO}_{2}$ emission from the soil. Studies carried out in Southern Brazil at an altitude of $46 \mathrm{~m}$ (Costa et al., 2008) and in the Savanna region at 452 $\mathrm{m}$ (Moitinho et al., 2013), reported that temperature is one factor that controls the emission of $\mathrm{CO}_{2}$. Moreover, NTS and ICLS reduce both soil temperature (Costa et al., 2008; Moitinho et al., 2013) and soil moisture in the surface soil layer (Rastogi et al., 2002), and they have the potential to modify $\mathrm{CO}_{2}$ emission rates.

Carbon dioxide emission data from cropping systems are scarce in Tocantins state. The efforts to measure $\mathrm{CO}_{2}$ emissions in croplands are crucial to subsidize the contributions of intensive agricultural systems to offset the $\mathrm{CO}_{2}$ emissionss and to meet the goals established to ABC Plan (Brazil, 2016). The study was aimed to: i) evaluate the potential of $\mathrm{CO}_{2}$ emission of a Oxisol under the ICLS and NTS in a region of the Tocantins brazilian Savanna characterized by low altitude; and ii) analyze the impact of soil temperature and soil moisture as factors that regulate the seasonality of $\mathrm{C}-\mathrm{CO}_{2}$ emissions under these systems.

\section{Method}

\subsection{Characterization of the Study Area}

Field-scale study was carried out at Fazenda Brejinho ( $\left.9^{\circ} 6^{\prime} 14.26^{\prime \prime} \mathrm{S}, 48^{\circ} 9^{\prime} 5.67^{\prime \prime} \mathrm{W}\right)$ in Pedro Afonso-TO. The climate in the region is characterized as Aw (Alvares et al., 2013), tropical humid, with dry winters, maximum rainfall in the summer, an average annual temperature of $26.1{ }^{\circ} \mathrm{C}$ and an average annual rainfall of $1714.9 \mathrm{~mm}$ (Alvares et al., 2013) (Table 1). The dry period is between May and September and the rainy period from October to April. The soil is classified according to the international classification Oxisol and according to the Brazilian Soil Classification Latossolo Vermelho Distrófico (Santos et al., 2018). The systems investigated were: 1) Brazilian Savanna with an area of 20 ha; 2) No-tillage with a soybean-corn rotation (NTS-SCS) with an area of 97 ha; 3) Integrated Crop-Livestock systems with a soybean-corn rotation (ICLS-SCS) with an area of 107 ha; 4) Integrated Crop-Livestock system with a pasture cycle (ICLS-PC) in an area of 87 ha. The experimental areas were localized nearby to avoid variation in altitude and soil variation. Soil physical and chemical attributes at topsoil layer $(0-20 \mathrm{~cm})$ of each area at the beginning of the study are shown in Table 2.

The NTS has been cropped for 14 years using the following cropping system soybean/corn or soybean/sorghum. After 6 years of NTS cycle, the ICLS was introduced in some farm fileds as a strategy to diversify production and farm income. Rotational grazing lasts 18 months in the ICLS (March of one year until October of the following year) with beef cattle in the rearing and fattening system. After grazing cycle end, soybeans are planted, where the same NTS crop systems are adopted. In the areas under ICLS used in this study, the pasture cycles occurred in 2009/2010 and 2014/2015 in the ICLS-PC and in 2009/10 in the ICLS-SCS. During the experimental period, the ICLS-SCS and NTS-SCS used soybean and corn whereas the ICLS-PC used pasture formed by Brachiaria brizantha cv. BRS Piatã. The pasture was rotated with a 28-day grazing interval and the cattle remained for 3 days in each paddock. 
Table 1. Historical average in the period from 1985 to 2014 and the year 2015 precipitation and maximum (Tmax), minimum (Tmin), average (Tmed) temperatures of the city of Pedro Afonso, TO

\begin{tabular}{|c|c|c|c|c|c|c|c|c|}
\hline \multirow{2}{*}{ Month } & \multicolumn{2}{|c|}{ Precipitation } & \multicolumn{2}{|c|}{ Tmax } & \multicolumn{2}{|c|}{ Tmin } & \multicolumn{2}{|c|}{ Tmed } \\
\hline & 2015 & 30 years & 2015 & 30 years & 2015 & 30 years & 2015 & 30 years \\
\hline & \multicolumn{2}{|c|}{-------- $\mathrm{mm}$-------- } & \multicolumn{6}{|c|}{ - --- } \\
\hline January & 257 & 284 & 32 & 32 & 22 & 22 & 26 & 27 \\
\hline February & 199 & 237 & 32 & 31 & 22 & 22 & 26 & 27 \\
\hline March & 215 & 272 & 32 & 31 & 23 & 23 & 26 & 27 \\
\hline April & 211 & 180 & 32 & 32 & 23 & 23 & 27 & 28 \\
\hline May & 96 & 64 & 33 & 33 & 23 & 22 & 27 & 28 \\
\hline June & 0 & 5 & 34 & 34 & 21 & 20 & 26 & 27 \\
\hline July & 0 & 4 & 35 & 35 & 20 & 19 & 27 & 27 \\
\hline
\end{tabular}

Source: Data from the INMET; Bortolon et al. (2016).

Table 2. Chemical and physical attributes $\S$ of soil in the layer of 0-20 cm, under native Savanna conditions and different systems of agricultural production, in Fazenda Brejinho-Pedro Afonso-TO

\begin{tabular}{llllllllllll}
\hline Sistemas & $\mathrm{pH}^{\S}$ & $\mathrm{P}$ & $\mathrm{K}$ & $\mathrm{Ca}$ & $\mathrm{Mg}$ & $\mathrm{Al}$ & $\mathrm{H}+\mathrm{Al}$ & $\mathrm{CO}$ & $\mathrm{Clay}$ & Silt & Sand \\
\hline & $\mathrm{H}_{2} \mathrm{O}$ & $-1---\mathrm{mg} \mathrm{kg}^{-1}----$ & ---15 & 0.45 & 2.00 & 11.10 & 22.3 & 514 & 222 & 263 \\
Savanna & 5.14 & 2.33 & 0.15 & 0.15 & 0.45 & \\
NTS-SCS & 5.42 & 22.4 & 0.33 & 4.30 & 1.55 & 0.18 & 4.52 & 14.8 & 419 & 217 & 365 \\
ICLS-SCS & 5.52 & 15.1 & 0.26 & 4.60 & 1.04 & 0.15 & 4.90 & 16.5 & 617 & 202 & 181 \\
ICLS-PC & 5.79 & 11.9 & 0.37 & 3.07 & 1.22 & 0.20 & 4.72 & 18.0 & 537 & 193 & 270 \\
\hline
\end{tabular}

Note. ${ }^{\S}$ Teixeira et al. (2017). $\mathrm{P}$ and $\mathrm{K}$ available from the solution of Mehlich ${ }^{-1} ; \mathrm{Ca}, \mathrm{Mg}, \mathrm{Al}$ exchangeable solution extracted from $\mathrm{KCl} 1.0 \mathrm{~mol} \mathrm{~L}^{-1} ; \mathrm{H}+\mathrm{Al}$ extracted by the calcium acetate solution $0.5 \mathrm{~mol} \mathrm{~L}^{-1}$ at $\mathrm{pH} 7.0$; Organic carbon extracted by dry combustion; clay, silt and sand determined by the pipette method after dispersion with $\mathrm{NaOH} 1.0 \mathrm{~mol} \mathrm{~L}{ }^{-1}$. NTS-SCS: No-tillage with a soybean-corn succession cycle; ICLS-SCS: Integrated Crop-Livestock with a soybean-corn succession cycle; ICLS-PC: Integrated Crop-Livestock with a pasture cycle.

\subsection{Emission of Carbon Dioxide}

The emission of $\mathrm{C}-\mathrm{CO}_{2}$ from the soil due to the respiration of the edaphic microbiota and the plant roots in each system was evaluated by capturing the $\mathrm{CO}_{2}$ using the alkaline medium method (Anderson, 1982), using a static chamber. In each system, a homogeneous subarea $(20 \times 20 \mathrm{~m})$ was selected and three static chambers were deployed in an equilateral triangular format, with $5 \mathrm{~m}$ between each chamber. The chambers were constructed as polyvinyl chloride (PVC) cylinders $\left(0.29 \mathrm{~m}\right.$ long, internal diameter $0.30 \mathrm{~m}$ and internal volume $\left.0.020 \mathrm{~m}^{3}\right) \mathrm{made}^{2}$ from with one of the extremities closed and the other open. At each sampling point, a circular pit was opened with a depth of 3-6 cm so that the extremity of the chamber could be buried in the soil, avoiding the gas exchange directly with the atmosphere. The chamber was deployed between lines or grass clumps so that only $\mathrm{CO}_{2}$ released from the soil was captured. The pits were opened 24 hours prior the installation of the chambers. The pits were opened carefully avoiding soil mobilization into the sampling area that could affect soil respiration results. Immediately before chamber installation (between 17:00-18:00), a flask containing $20 \mathrm{~mL} \mathrm{of} 0.5 \mathrm{~mol} \mathrm{~L}^{-1}$ $\mathrm{NaOH}$ was opened, positioned in the middle of the pit and the chamber was positioned over the flask (Araujo et al., 2011). Soil was then used to seal the borders of the chamber to minimize gaseous exchange with the atmosphere. This procedure is important to keep $\mathrm{CO}_{2}$ released from soil contained within the chamber and captured by the $\mathrm{NaOH}$. After 15 hours, the chambers were opened and immediately were added $3.0 \mathrm{~mL} \mathrm{of} \mathrm{BaCl}$ $(30 \%)$ into the flask with $\mathrm{NaOH}$ solution; flasks were hermetically sealed and stored for further titration with 0.3 mol L ${ }^{-1} \mathrm{HCl}$. Soil temperature and soil moisture was measured in the chamber at depth of 1-6 $\mathrm{cm}$ using the POGO Hydra Probe II (Stevens). The emission of $\mathrm{C}-\mathrm{CO}_{2}$ was quantified between January and July 2015, according to the developmental stage of the grain crops (26/01/15-soybean R6, 13/02/2015-soybean R7, 08/03/2015-corn V3, 01/04/2015-corn R1 and 16/07/2015-corn pre-harvest). These sampling dates were chosen during the periods when the pasture paddocks under ICLS-PC (grazing cycle) system, were without the animals to prevent damages in the chambers. 


\subsection{Statistical Analyses}

The C- $\mathrm{CO}_{2}$ emissions, soil temperature and soil moisture data were submitted to the Shapiro Wilk test to confirm the assumptions of the analysis of variance (ANOVA). ANOVA was applied as random plot design, considering the production systems as the plots with three replicates. The means, when significant, were compared using the Duncan test at the 5\% significance level. Pearson correlation analysis was carried out on the data from the $\mathrm{C}-\mathrm{CO} 2$ emissions, soil temperature and soil moisture. Analyses were performed using the R package (R Studio Team, 2016) and the ANOVA analyses using ExpDes (Ferreira et al., 2013).

\section{Results}

\subsection{Emissions of $\mathrm{C}-\mathrm{CO}_{2}$ From the Soil Under Different Agricultural Systems}

The emissions of $\mathrm{C}-\mathrm{CO}_{2}$ from the soil under different agricultural systems are shown in Table 3. In January, the emission under ICLS-PC was the highest $\left(132.7 \mathrm{mg} \mathrm{m}^{-2} \mathrm{~h}^{-1}\right)$, compared to NTS-SCS $\left(122.6 \mathrm{mg} \mathrm{m}^{-2} \mathrm{~h}^{-1}\right)$ and ICLS-SCS $\left(121.2 \mathrm{mg} \mathrm{m}^{-2} \mathrm{~h}^{-1}\right)$. In February, the data followed the same tendency with ICLS-PC with the observed highest emission $\left(224.6 \mathrm{mg} \mathrm{m}^{-2} \mathrm{~h}^{-1}\right)$ that was significantly different from the Savanna $\left(214.2 \mathrm{mg} \mathrm{m}^{-2}\right.$ $\mathrm{h}^{-1}$ ); lower emissions were observed for NTS-SCS and ICLS-SCS, 153.6 and $151.0 \mathrm{mg} \mathrm{m}^{-2} \mathrm{~h}^{-1}$, respectively. However, in March, the lowest emissions were observed in both Savanna $\left(53.6 \mathrm{mg} \mathrm{m}^{-2} \mathrm{~h}^{-1}\right)$ and ICLS-SCS (58.8 $\left.\mathrm{mg} \mathrm{m}^{-2} \mathrm{~h}^{-1}\right)$ and the highest emissions were observed in NTS-SCS $\left(104.8 \mathrm{mg} \mathrm{m}^{-2} \mathrm{~h}^{-1}\right)$.

The C- $\mathrm{CO}_{2}$ emission patterns were similar for all agricultural systems evaluated, including the Savanna, where maximum emissions were observed in February and the minimum in July; which indicates a normal seasonality in $\mathrm{C}_{-} \mathrm{CO}_{2}$ emissions, according to the climatic characteristics of each region. The low altitude Savanna is characterized by high temperatures, a rainy summer (February) and a dry winter (Salimon et al., 2004), which directly influences the soil temperature and soil moisture. The historical average rainfall in July is $0 \mathrm{~mm}$ (Table 1) which reduces soil water content and may have caused low $\mathrm{C}-\mathrm{CO}_{2}$ emissions, since water is a limiting factor for microbial activity (Fierer \& Jackson, 2006)

Phenological stage and plant physiology during the growing season coupled with different agricultural systems can impact directly, indirectly or residual effects on C-CO $\mathrm{CO}_{2}$ emissions. The ICLS-PC emitted a plus of $33 \mathrm{mg} \mathrm{m}^{-2}$ $\mathrm{h}^{-1}$ of $\mathrm{C}-\mathrm{CO}_{2}$ compared with ICLS-SCS, on average. This effect could be attributed to the permanence of the plants in the vegetative stage (high root activity) during the experimental period, causing higher biological activity (Salton et al., 2014) due to root respiration (Cecato et al., 2004).

It is important to point it out that every 28 days this area had 3 days of grazing and the removal of the aboveground biomass by cattle stimulates thin root growth (Bai et al., 2015) and the release of root exudates (Shahzad et al., 2012). These exudates consist mainly of polysaccharides, organic acids and amino acids (Chen et al., 2016) that are organic compounds easily metabolized by the microbiota when they are not associated with soil clay minerals (Cotrufo et al., 2015). These conditions contribute to the increase in activity and consequent increase in microbial respiration of the soil. However, the higher $\mathrm{C}-\mathrm{CO}_{2}$ emissions observed in the ICLS-PC is possibly due to the increased activity and thin root growth of the Brachiaria forage grass caused by grazing, which in turn stimulated the higher activity of the edaphic microbiota. Considering that most of the respiration from the pasture soils is either from root respiration of the grasses or from microbial decomposition of $\mathrm{C}$ (Salimon et al., 2004).

The results should be interpreted with caution, since in the case of the high $\mathrm{C}-\mathrm{CO}_{2}$ emissions observed in the ICLS-PC should not be interpreted in a negative way, such that this system is characterized as an emitter and not a $\mathrm{C}-\mathrm{CO}_{2}$ sink. Therefore, it is necessary to make an analysis of the balance between the $\mathrm{C}$ addition to and the emission of $\mathrm{C}-\mathrm{CO}_{2}$ from the soil for each agricultural system. Those systems where the $\mathrm{C}-\mathrm{CO}_{2}$ balance is negative (emission higher than the addition of $\mathrm{C}$ to the soil) are considered $\mathrm{CO}_{2}$ emitters while those systems where the $\mathrm{C}-\mathrm{CO}_{2}$ balance is positive (addition is higher than the emission of $\mathrm{C}$ from the soil) are considered $\mathrm{C}$ sinks. However, this analysis was not one of the objectives of the present study. Based on the $\mathrm{C}-\mathrm{CO}_{2}$ emission results (Table 3), it is possible to infer that the ICLS-PC system acts to mitigate $\mathrm{CO}_{2}$ emissions from edaphic respiration (microorganisms and roots). This system could add to the soil at least 2,865 kg ha $\mathrm{yr}^{-1}$ of C (10,503 $\mathrm{kg} \mathrm{ha}^{-1} \mathrm{yr}^{-1}$ of C-CO $\mathrm{CO}_{2}$ ) if an average $\mathrm{CO}_{2}$ emission rate $\left(119.9 \mathrm{mg} \mathrm{m}^{-2} \mathrm{~h}^{-1}\right.$ of $\mathrm{C}_{-} \mathrm{CO}_{2}$, Table 3$)$ is considered during the experimental period. However, this could increase to at least $5,366 \mathrm{~kg} \mathrm{ha}^{-1} \mathrm{yr}^{-1}$ of C $\left(19,675 \mathrm{~kg} \mathrm{ha}^{-1} \mathrm{yr}^{-1}\right.$ of $\left.\mathrm{C}-\mathrm{CO}_{2}\right)$ if the highest $\mathrm{CO}_{2}$ emission rate is considered $\left(224.6 \mathrm{mg} \mathrm{m}^{-2} \mathrm{~h}^{-1}\right.$ of $\mathrm{C}_{-} \mathrm{CO}_{2}$, Table 3), which was observed in February. In the other systems studied, for the $\mathrm{CO}_{2}$ emissions from microbial soil respiration to be mitigated, these systems should provide additions to the soil of at least $2,088 \mathrm{~kg} \mathrm{ha}^{-1} \mathrm{yr}^{-1}$ of C under the ICLS-SCS and $2,370 \mathrm{~kg} \mathrm{ha}^{-1} \mathrm{yr}^{-1}$ of C under the NTS-SCS system if average emission levels are considered. Values of at least 
3,608 and 3,670 $\mathrm{kg} \mathrm{ha}^{-1} \mathrm{yr}^{-1}$ of $\mathrm{C}$ could be achieve if maximum emission levels are considered under ICLS-SCS and NTS-SCS, respectively, observed in February.

In addition, the ICLS has a residual effect on the soil system and in this study a reduction of $12 \%$ in $\mathrm{C}^{-\mathrm{CO}_{2}}$ emissions was observed from the soil under ICLS-SCS when compared to the NTS-SCS. This could be explained by the capacity of the Brachiaria root system in physically protecting soil organic carbon (SOC) in the soil aggregates (Salimon et al., 2004; Salton et al., 2014). In addition, there is probably a stabilizing effect of the aggregates due to the release of polysaccharides in the form of root exudates, which are cementing agents of the soil particles (Tisdall \& Oades, 1982; Six et al., 2004), thus improving soil structure (D'Andréa et al., 2004). Thus, ICLS can be considered a biologically active system, which results in the rapid cycling of nutrients and mitigation of $\mathrm{CO}_{2}$ emissions.

\subsection{Soil Temperature and Soil Moisture and Its Relations With the Emission of $\mathrm{C}-\mathrm{CO}_{2}$ From the Soil}

During the evaluation period, soil temperature differed among agricultural systems (Table 3). In February, March and April, the soil temperature was lower in the Savanna ranging from 23.4 to $29.6{ }^{\circ} \mathrm{C}$ (Table 3). This indicates that under natural conditions with different plant strata, such as tree plants, shrubs, creeping plants, and the constant deposition of organic material, the soil is protected from direct solar radiation reducing the soil temperature. In the case of the anthropic systems under study, the soil temperature varied according to agricultural system, and a difference among treatments was observed (Table 3). In January, February, April and July the ICLS-SCS system presented the highest soil temperatures (Table 3).

The different crop phenological stages in each period evaluated may have contributed to the oscillation in soil temperature and, consequently, influenced the seasonality of $\mathrm{C}-\mathrm{CO}_{2}$ emissions. In February, the systems cultivated with soybean under ICLS and NTS presented the highest temperatures 33.7 and $32.1{ }^{\circ} \mathrm{C}$, respectively (Table 3). During this period, the soybean was in the physiological stage R7, when the accumulation of dry mass of the grain ends and the leaves begin to fall, the stem, the branches, the pods and the grains lose moisture. As a result, there is a higher incidence of solar radiation directly reaching the soil surface, increasing the soil temperature. In March, the corn in these systems was in the vegetative stage, the soil cover by the plants was at its highest contributing to the observed reduction in soil temperatures in relation to the previous month. The ICLS-SCS system registered a temperature of $23.4{ }^{\circ} \mathrm{C}$, while NTS-SCS registered the highest temperature for the month of March $25.1^{\circ} \mathrm{C}$ (Table 3). In April, the highest temperatures were registered in the soil under ICLS and lower temperatures under Savanna and under both systems cultivating corn (ICLS-SCS and NTS-SCS), with the crop at the reproductive stage R8. Thus, the crop phenological stage in the field altered the amount of soil coverage, which interfered with the variation of the temperature of the soil.

Soil temperature influenced seasonality and the emission of $\mathrm{C}-\mathrm{CO}_{2}$ (Table 3). The correlation between soil temperature and $\mathrm{C}-\mathrm{CO}_{2}$ emission was positive $\left(\mathrm{r}=0.899^{* *}\right)$ (Figure 1). High temperatures accelerate microbial metabolism (Karhu et al., 2014), cellular multiplication occurs, increasing microbial populations, with a higher quantity of enzymes being released into the soil the degradation of organic compounds in the soil occurs, consequently increasing the emission of C- $\mathrm{CO}_{2}$. Similar results were observed by Costa et al. (2008), Iamaguti et al. (2015) and Goodrick et al. (2016) in grain production systems in Rio Grande do Sul, sugarcane plantation of São Paulo State and an Australian forest, respectively.

An influence of the management system on soil moisture was also identified. In April and July, the moisture under NTS-SCS was the lowest (Table 3). During April, the corn was at the grain-filling phase, which has the greatest demand on the hydric resources of the plant. However, using the ICLS-SCS, under the same crop and at the same time of year, soil moisture was $6.3 \%$ higher (Table 3). The difference in soil moisture between these two systems may be due to the composition of the crop system adopted and the characteristics of the plant species involved. The ICLS uses forage grasses, plants with fasciculated root systems that have the potential to improve soil structure and form micro-channels during root cycling. These small spaces contribute to the overall soil water storage capacity that could be used by the corn roots later. Soil moisture behaved in the same way as temperature during the experimental period. In general, soil moisture had a positive correlation with the emission of $\mathrm{C}-\mathrm{CO}_{2}\left(\mathrm{r}=0.70^{* * *}\right)$ (Figure 1), as expected. This is because the increase in the water content of the soil favors microbial activity. 
Table 3. Carbon dioxide emission $\left(\mathrm{C}-\mathrm{CO}_{2}\right)$, average temperature and soil moisture, in the months of January, February, March, April and July of the year 2015 under conditions of native Savanna and different systems of agricultural production, in the Fazenda Brejinho-Pedro Afonso-TO

\begin{tabular}{|c|c|c|c|c|c|c|}
\hline \multirow{2}{*}{ System $^{\S}$} & \multicolumn{6}{|c|}{ Months under evaluation } \\
\hline & January & February & March & April & June & Average \\
\hline & \multicolumn{6}{|c|}{ - Emission $\mathrm{C} \mathrm{CO}_{2}\left(\mathrm{mg} \mathrm{m}^{-2} \mathrm{~h}^{-1}\right)$ - } \\
\hline Savanna & $126.5 \mathrm{ab}^{*}( \pm 5.84)$ & $214.2 \mathrm{a}( \pm 20.01)$ & $53.6 \mathrm{~b}( \pm 7.8)$ & $46.7 \mathrm{~b}( \pm 23.71)$ & $32.6 \mathrm{a}( \pm 3.33)$ & $89.7 \mathrm{bc}( \pm 6.75)$ \\
\hline NTS-SCS & $122.6 \mathrm{~b}( \pm 2.61)$ & $153.6 \mathrm{~b}( \pm 3.42)$ & $104.8 \mathrm{a}( \pm 1.6)$ & $99.3 \mathrm{a}( \pm 21.26)$ & $15.8 \mathrm{~b}( \pm 4.79)$ & $99.2 \mathrm{~b}( \pm 3.90)$ \\
\hline ICLS-SCS & $121.2 \mathrm{~b}( \pm 2.70)$ & $151.0 \mathrm{~b}( \pm 2.12)$ & $58.8 \mathrm{~b}( \pm 2.04)$ & $102.4 \mathrm{a}( \pm 2.12)$ & $3.7 \mathrm{c}( \pm 2.24)$ & 87.4 c $( \pm 4.21)$ \\
\hline ICLS-PC & 132.7 a $( \pm 0.96)$ & $224.6 \mathrm{a}( \pm 2.02)$ & 86.9 a $( \pm 12.69)$ & $125.3 \mathrm{a}( \pm 24.47)$ & 30.2 a $( \pm 5.59)$ & 119.9 a $( \pm 2.43)$ \\
\hline Value $p>F$ & $1.56 \mathrm{E}^{-02}$ & $5.30 \mathrm{E}^{-04}$ & $9.9 \mathrm{E}^{-05}$ & $8.0 \mathrm{E}^{-02}$ & $9.43 \mathrm{E}^{-05}$ & $1.45 \mathrm{E}^{-04}$ \\
\hline \multirow[t]{2}{*}{$\mathrm{CV} \%$} & 2.8 & 7.9 & 9.9 & 21.5 & 20.4 & 4.6 \\
\hline & \multicolumn{6}{|c|}{ Average soil temperature $\left({ }^{\circ} \mathrm{C}\right)$ - } \\
\hline Savanna & $29.6 \mathrm{~b}( \pm 0.86)$ & $29.6 \mathrm{~b}( \pm 0.31)$ & $23.4 \mathrm{c}( \pm 0.00)$ & $24.9 \mathrm{c}( \pm 0.06)$ & $22.1 \mathrm{a}( \pm 0.10)$ & 26.9 a $( \pm 0.09)$ \\
\hline NTS-SCS & $26.9 \mathrm{c}( \pm 0.32)$ & $32.1 \mathrm{a}( \pm 0.06)$ & $25.1 \mathrm{a}( \pm 0.12)$ & $26.1 \mathrm{~b}( \pm 0.06)$ & 22.9 a $( \pm 1.05)$ & $26.6 \mathrm{a}( \pm 0.12)$ \\
\hline ICLS-SCS & $31.7 \mathrm{a}( \pm 0.06)$ & $33.7 \mathrm{a}( \pm 0.31)$ & $23.4 \mathrm{c}( \pm 0.55)$ & $26.6 \mathrm{a}( \pm 0.46)$ & $23.1 \mathrm{a}( \pm 1.59)$ & $27.7 \mathrm{a}( \pm 0.15)$ \\
\hline ICLS-PC & $31.1 \mathrm{a}( \pm 0.21)$ & $29.8 \mathrm{~b}( \pm 0.46)$ & $24.3 \mathrm{~b}( \pm 0.35)$ & 27.0 a $( \pm 0.06)$ & $20.3 \mathrm{~b}( \pm 0.40)$ & $26.5 \mathrm{a}( \pm 0.18)$ \\
\hline Value $r p>F$ & $7.19 \mathrm{E}^{-06}$ & $6.83 \mathrm{E}^{-07}$ & $7.20 \mathrm{E}^{-04}$ & $1.64 \mathrm{E}^{-05}$ & $2.63 \mathrm{E}^{-02}$ & $3.65 \mathrm{E}^{-01}$ \\
\hline \multirow[t]{2}{*}{ CV\% } & 1.6 & 1.0 & 1.4 & 0.9 & 4.4 & 3.1 \\
\hline & \multicolumn{6}{|c|}{ (\%) -- } \\
\hline Savanna & $0.2 \mathrm{c}( \pm 0.02)$ & $0.1 \mathrm{c}( \pm 0.03)$ & $19.7 \mathrm{c}( \pm 2.40)$ & $20.1 \mathrm{a}( \pm 2.13)$ & $20.1 \mathrm{a}( \pm 1.54)$ & $12.2 \mathrm{a}( \pm 0.75)$ \\
\hline NTS-SCS & $0.3 \mathrm{bc}( \pm 0.02)$ & $0.2 \mathrm{~b}( \pm 0.01)$ & $32.0 \mathrm{a}( \pm 5.76)$ & $9.3 \mathrm{c}( \pm 0.67)$ & $9.3 \mathrm{c}( \pm 2.57)$ & $14.5 \mathrm{a}( \pm 1.48)$ \\
\hline ICLS-SCS & $0.4 \mathrm{a}( \pm 0.06)$ & $0.3 \mathrm{a}( \pm 0.02)$ & $29.2 \mathrm{ab}( \pm 4.45)$ & $15.6 \mathrm{~b}( \pm 5.8)$ & $15.6 \mathrm{~b}( \pm 0.42)$ & $15.7 \mathrm{a}( \pm 2.12)$ \\
\hline ICLS-PC & $0.4 \mathrm{a}( \pm 0.02)$ & $0.2 \mathrm{~b}( \pm 0.07)$ & $23.6 \mathrm{bc}( \pm 1.97)$ & $15.4 \mathrm{~b}( \pm 1.58)$ & $15.4 \mathrm{~b}( \pm 2.05)$ & $14.4 \mathrm{a}( \pm 1.07)$ \\
\hline Value $p>F$ & $4.60 \mathrm{E}^{-03}$ & $8.6 \mathrm{E}^{-03}$ & $2.08 \mathrm{E}^{-02}$ & $5.7 \mathrm{E}^{-03}$ & $7.0 \mathrm{E}^{-04}$ & $8.9 \mathrm{E}^{-02}$ \\
\hline $\mathrm{CV} \%$ & 12.6 & 25.0 & 15.1 & 10.9 & 12.1 & 10.1 \\
\hline
\end{tabular}

Note. ${ }^{\S}$ NTS-SCS: No-tillage with a soybean-corn succession cycle; ICLS-SCS: Integrated Crop-Livestock with a soybean-corn succession cycle; ICLS-PC: Integrated Crop-Livestock with a pasture cycle. ${ }^{*} \mathrm{p}>0.05$ by Duncan's test $(\mathrm{p}<0.05)$. Values in parentheses represent standard deviation for spatial term variation.
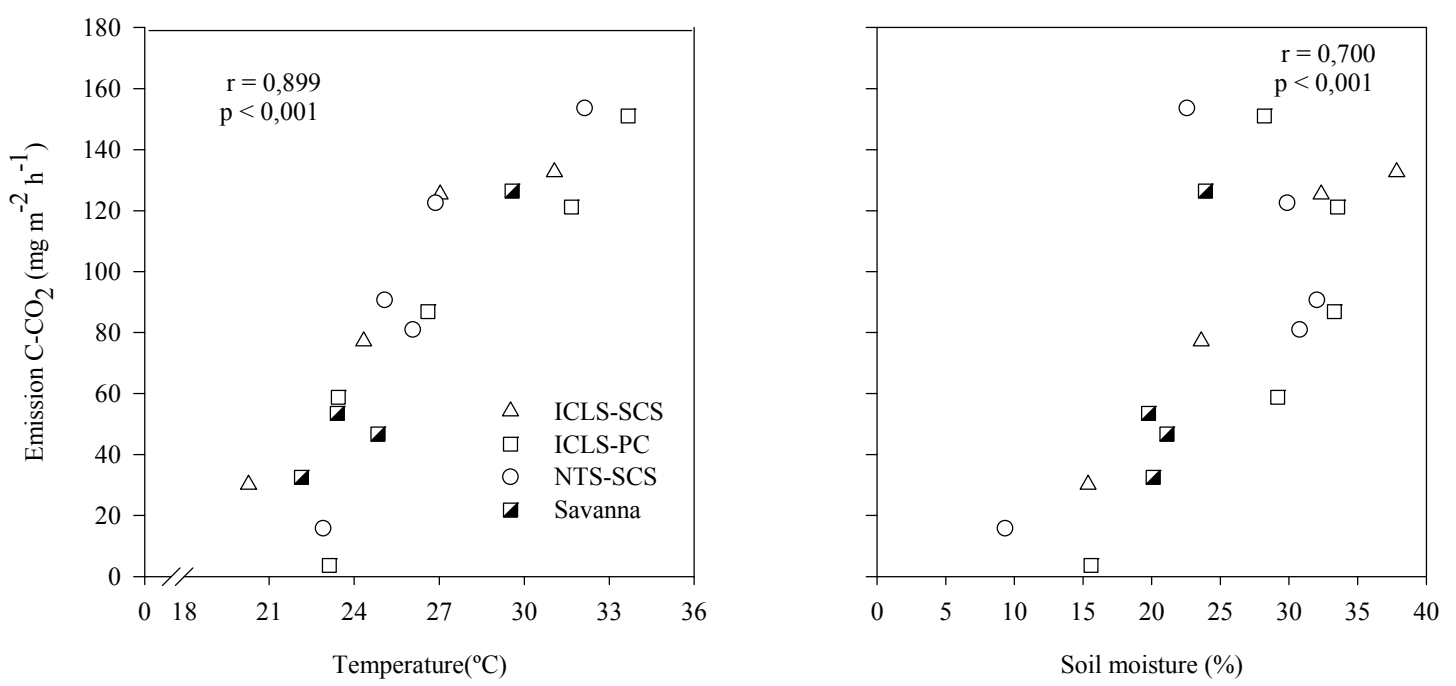

Figure 1. Correlation between temperature and mean soil moisture with the emission of $\mathrm{C}-\mathrm{CO}_{2}\left(\mathrm{mg} \mathrm{m}^{-2} \mathrm{~h}^{-1}\right)$ at Fazenda Brejinho in the city of Pedro Afonso (TO)

\section{Conclusion}

The soil temperature and soil moisture and the agricultural system contribute to the emission and seasonality of carbon dioxide emissions from the soil. 
The integrated crop-livestock system, during the crop cycle, had the largest capacity to mitigate carbon dioxide emissions, due to the residual action of the Brachiaria forage grass.

The integrated crop-livestock system, during the grazing cycle, had the greatest potential for carbon dioxide emission from the soil, which may be due to the respiration of grass roots and soil microbiota.

\section{Acknowledgements}

We are grateful for efforts of the owners of Brejinho farm to give us access to the fields and all support needed to conduct this field research.

\section{References}

Anderson, J. P. E. (1982). Soil respiration. In A. L. Page, R. H. Miller, \& D. R. Keeney (Eds.), Chemical and Biological Properties (2nd ed., Agronomy Monograph Number 9, Part II). American Society of Agronomy and Soil Science Society of America: Madison.

Alvares, C. A., Stape J. L., Sentelhas, P. C., Gonçalves, J. L. M., \& Sparovek, G. (2013). Koppen's climate classification map for Brazil Clayton. Meteorol Zeitschrift, 22, 711-728. https://doi.org/10.1127/0941-2948/ 2013/0507

Araujo, K. D., Dantas, R. T., Andrade, A. P., \& Parente, H. N (2011). Cinética de evolução de dióxido de carbono em área de Caatinga em São João do Cariri-PB. Revista Árvore, 35, 1099-1106.

Bai, W., Fang, Y., Zhou, M., Xie, T., Li, L., \& Zhang, W. (2015). Heavily intensidied grazing reduces root production in an Mongolia temperate steppe. Agriculture, Ecosystems and Environment, 200, 143-150. https://doi.org/10.1016/j.agee.2014.11.015

Bayer, C., Gomes, J., Zanatta, J. A., Vieira, F. C. B., \& Dieckow, J (2016). Mitigating greenhouse gas emissions from a subtropical Ultisol by using long-term no-tillage in combination with legume cover crops. Soil and Tillage Research, 161, 86-94. https://doi.org/10.1016/j.still.2016.03.011

Bayer, C., Martin-Neto, L., Mielniczuk, J., Pavinato, A., \& Dieckow, J. (2006). Carbon sequestration in two Brazilian Savanna soils under no-till. Soil and Tillage Research, 86, 237-245. https://doi.org/10.1016/ j.still.2005.02.023

Bortolon, E. S. O., Souza, J. P., Bortolon, L., Evangelista, B. A., \& Donagemma, G. K. (2016). Caracterização climática da região de Pedro Afonso-TO no período de 1985 a 2014. Palmas, Brazil: Embrapa Pesca e Aquicultura.

Blaud, A., Lerch, T. Z., Chevallier, T., Nunan, N., Chenu, C., \& Brauman, A. (2012). Dynamics of bacterial communities in relation to soil aggregate formation during the decomposition of $13 \mathrm{C}$-labelled rice straw. Applied Soil Ecology, 53, 1-9. https://doi.org/10.1016/j.apsoil.2011.11.005

Carvalho, J. L. N., Cerri, C. E. P., Feigl, B. J., Píccolo, M. C., Godinho, V. P., \& Cerri, C. C. (2009). Carbon sequestration in agricultural soils in the Savanna region of the Brazilian Amazon. Soil and Tillage Research, 103, 342-349. https://doi.org/10.1016/j.still.2008.10.022

Cecato, U., Pereira, L. A. F., Galbeiro, S., Santos, G. T., Damasceno, J. C. Dos, \& Machado, A. O. (2004). Influência das adubações nitrogenada e fosfatada sobre a produção e características da rebrota do capim Marandu (Brachiaria brizantha (Hochst) Stapf cv. Marandu). Acta Scientiarum. Animal Sciences, 26, 399-407.

Chen, Z. J., Tian, Y. H., Zhang, Y., Song, B. R., Li, H. C., \& Chen, Z. H. (2016). Effects of root organic exudates on rhizosphere microbes and nutrient removal in the constructed wetlands. Ecological Engineering, 32, 243-250. https://doi.org/10.1016/j.ecoleng.2016.04.001

Costa, F. D. S., Bayer, C., Zanatta, J. A., \& Mielniczuk, J (2008). Estoque de carbono orgânico no solo e emissões de dióxido de carbono influenciadas por sistemas de manejo no sul do Brasil. Revista Brasileira Ciência do Solo, 32, 323-332.

Cotrufo, M. F., Soong, J. L., Horton, A. J., Campbell, E. E., Haddix, M. L., Wall, D. H., \& Parton, W. J (2015). Formation of soil organic matter via biochemical and physical pathways of litter mass loss. Nature Geoscience, 8, 776-779. https://doi.org/10.1038/NGEO2520

D'andréa, A. F., Silva, M. L. N., Curi, N., \& Guilherme, L. R. G. (2004). Carbon and nitrogen storage, and inorganic nitrogen forms in a soil under different management systems. Pesquisa Agropecuária Brasileira, $39,179-186$. 
Dippold, M. A., \& Kuzyakov, Y. (2013). Biogeochemical transformations of amino acids in soil assessed by position-specific labelling. Plant and Soil, 373, 385-401. https://doi.org/10.1007/s11104-013-1764-3

Donagemma, G. K., Freitas, P. L. de, Balieiro, F. de C., Fontana, A., Spera, S. T., Lumbreras, J. F., Viana, ... Bortolon, L. (2016). Characterization, agricultural potential, and perspectives for the management of light soils in Brazil. Pesquisa Agropecuária Brasileira, 51, 1003-1020. https://doi.org/10.1590/S0100-204X 2016000900001

Ferreira, E. B., Cavalcanti, P. P., \& Nogueira, D. A. (2013). ExpDes: Experimental Designs package (R Package Version 1.1.2). Retrieved from https://CRAN.R-project.org/package=ExpDes

Fierer, N., \& Jackson, R. B. (2006). The diversity and biogeography of soil bacterial communities. Proceedings of the National Academy of Sciences of the United States of America, 103, 626-631. Retrieved from https://doi.org/10.1073/pnas.0507535103

Goodrick, I., Connor S., Bird M. I., \& Nelson P. N. (2016). Emission of CO2 from tropical riparian forest soil is controlled by soil temperature, soil water content and depth to water table. Soil Research, 54, 311-320. https://doi.org/10.1071/SR15040

Horvat, R., Watanabe, M., \& Yamaguchi, C. K. (2015). Fertilizer consumption in the region MATOPIBA and their reflections on Brazilian soybean production. International Journal of Agriculture and Forestry, 5, 52-59. https://doi.org/10.5923/j.ijaf.20150501.08

Iamaguti, J. L., Moitinho, M. R., Teixeira, D. D. B., Bicalho, E. da S., Panosso, A. R., \& Junior, N. L. S. (2015). Zona de manejo para preparo do solo na cultura da cana-de-açúcar. Revista Brasileira Engenharia Agrícola e Ambiental, 19, 497-504. https://doi.org/10.1590/1807-1929/agriambi.v19n5p497-504

Karhu, K., Auffret, M. D., Dungait, J. A. J., Hopkins, D. W., Prosser, J. I., Singh, B. K., ... Hartley, I.P. (2014). Temperature sensitivity of soil respiration rates enhanced by microbial community response. Nature, 513, 81-84. https://doi.org/10.1038/nature13604

Lal, R. (2004). Agricultural activities and the global carbon cycle. Nutrient Cycling in Agroecosystems, 70, 103-116.

Moitinho, M. R., Padovan, M. P., Panosso, A. R., \& Junior, N. L. S. (2013). Efeito do preparo do solo e resíduo da colheita de cana-de-açúcar sobre a emissão de $\mathrm{CO}_{2}$. Revista Brasileira de Ciência do Solo, 37, 1720-1728.

Prado, R. B., Fidalgo, E. C. C., Monteiro, J. M. G., Schuler, A. E., Vezzani, F. M., Garcia, J. R., ... Simões, M (2016). Current overview and potential applications of the soil ecosystem services approach in Brazil. Pesquisa Agropecuária Brasileira, 51, 1021-1038. https://doi.org/10.1590/S0100-204X2016000900002

Rastogi, M., Singh, S., \& Pathak, H. (2002). Emission of carbon dioxide from soil. Current Science, 82, 510-517.

Salimon, C. I., Davidson, E. A., Victoria, R. L., \& Melo, A. W. F. (2004). CO2 flux from soil in pastures and forests in southwestern Amazonia. Global Change Biology, 10, 833-843. https://doi.org/10.1111/j.15298817.2003.00776.x

Salton, J. C., Mercante, F. M., Tomazi, M., Zanatta, J. A., Concenço, G., Silva, W. M., \& Retore, M. (2014). Integrated crop-livestock system in tropical Brazil: Toward a sustainable production system. Agriculture, Ecosystems \& Environment, 190, 70-79. https://doi.org/10.1016/j.agee.2013.09.023

Santos, H. G. dos, Jacomine, P. K. T., Anjos, L. H. C. dos, Oliveira, V. A. de, Lumbreras, J. F., Coelho, M. R.; Almeida, J. A. de, ... Cunha, T. J. F. (2018). Brazilian Soil Classification System. Embrapa: Brasília.

Shahzad, T., Chenu, C., Repinçay, C., Mouginc, C., Ollier, J., \& Fontaine, S. (2012). Plant clipping decelerates the mineralization of recalcitrant soil organic matter under multiple grassland species. Soil Biology and Biochemistry, 51, 73-80. https://doi.org/10.1016/j.soilbio.2012.04.014

Six, J., Bossuyt, H., Degryze, S., \& Denef, K (2004). A history of research on the link between (micro)aggregates, soil biota, and soil organic matter dynamics. Soil and Tillage Research, 79, 7-31. https://doi.org/10.1016/j.still.2004.03.008

Tisdall, J. M., \& Oades, J. M. (1982). Organic matter and water-stable aggregates in soils. Journal soil Science, 31, 141-163. 
Zhang, Z., Qiao, M., Li, D., Zhao, C., \& Li, Y. (2015). Effects of two root-secreted phenolic compounds from a subalpine coniferous species on soil enzyme activity and microbial biomass. Chemistry and Ecology, 31, 636-649. https://doi.org/10.1080/02757540.2015.1075515

\section{Copyrights}

Copyright for this article is retained by the author(s), with first publication rights granted to the journal.

This is an open-access article distributed under the terms and conditions of the Creative Commons Attribution license (http://creativecommons.org/licenses/by/4.0/). 